\title{
An ethnographic study of glocal fashion communication in Hong Kong and
}

\section{Greater China}

Ho-Lun Tommy Tse, University of Hong Kong

\begin{abstract}
The rise of fashion businesses in mainland China and Hong Kong and the growth in their brands is attracting the attention of international fashion conglomerates. For this article recent case studies of socio-historical, economic and cultural influences in the Greater China region were revisited applying communication, media and cultural studies theories. Observation and interviews were conducted in an attempt to reveal the nuanced process of fashion communication in Hong Kong's fashion industry.
\end{abstract} The primary research data were collected through participant observation at a Hong Kong fashion magazine in 2011 which involved interviews with sixteen senior Asia-Pacific fashion marketers. The interview responses demonstrate the complexity of the interplay with Asian socioeconomic and cultural factors, and confirm that fashion marketing in Hong Kong today involves the appropriation and creolization of cultural meanings through negotiation between global and regional/local fashion marketers. The Hong Kong-based regional fashion marketers now negotiate more often with the brands' European or American headquarters about how to represent the 
brands as luxurious and stylish, but also about a more complex creolization of western and Chinese cultures while communicating fashion meanings. This unique ethnographic research provides original insight into the differing impact of globalization across Greater China.

\section{Keywords}

creolization

fashion communication

fashion marketers

luxury brands

glocalization

participant observation

Hong Kong

China 


\section{Introduction}

This article reviews socioeconomic conditions across Greater China and the

Asia-Pacific region to sketch the social dynamics of glocal communication in Asia's

fashion industry. The term 'glocal' here is an extension of the concept of globalization;

that is, 'the processes by which the world becomes a single place' (King 1991: 151).

It refers to an increasing entanglement of the global and local spheres, and is used 'to designate the manner in which global products adapt or tailor themselves for local markets and sensitivities' (Mooney and Evans 2007: 117). In terms of advertising communication, such differing impact of globalization (Ger 1999) extends

\footnotetext{
the underlying assumption $[\ldots]$ that consumers in a less developed economy would either remain traditional and prefer advertising that matches local culture [...] or engage in a unidirectional adoption of Western cultural values [...] that promotes global culture [while] glocal understandings may entail a richer process than the one assumed in a dichotomization approach.
} (Hung, Li and Belk 2007: 1034-35)

This article first looks at fashion communications in the plural and at how and why neither top-down nor bottom-up communication is as effective as it should be in the Asian context. Second, rather than merely representing predetermined western styles 
or defending indigenous Hong Kong, Chinese or even Asian styles, the way

glocalized communication is executed, which involves subtle appropriation of Asian aesthetics and creolization of local cultures (Pieterse 1995), is elucidated.

\section{The recent economic boom in Asia and Greater China}

The recent economic recession in the West and its current financial problems, as in

Europe's eurozone, have left Greater China as a particularly alluring market for

fashion retailers from around the world. In the last three decades, China has

undergone drastic economic reforms and transformed itself into a much more

globalized and modern nation, wielding more power in economic affairs on the global

stage (Zhao 2013: 11). Due to its increasing population, its budget surpluses, the

rising pace of industrial and commercial development and its burgeoning middle class

with an increasing propensity to spend on consumable products, Greater China has

become a very attractive proposition for manufacturers seeking to maintain or

establish their brands (Lannes 2011). In contrast with the declining European and

weakening Japanese markets, Bain \& Company (2010) report that since 2010 the

Greater China market has been the world's third largest for luxury consumption,

constituting a leading stimulus after the global economic downturn in 2007 and the

drastic drop in sales elsewhere in 2008 and 2009 (Bain \& Company 2011; Lannes 
2011). Fashion and luxury marketing activities in mainland China have become much more active, visible and significant between 2010 and 2013 as a result (Bain \& Company 2010, 2011, 2013).

In 2010, the domestic luxury market in mainland China grew by 27 per cent and reached $¥ 87$ billion (Bain \& Company 2011). Meanwhile, Chinese consumers preferred to spend even more overseas due to the lower prices and the wider range of high-end products offered. In 2010 luxury spending in Hong Kong and Macau reached $¥ 72$ billion, growing by a substantial 44 per cent compared with the previous year, and accounted for about 34 per cent of the nation's total luxury consumption of $¥ 212$ billion spent in and outside the mainland (Bain \& Company 2011). The competition among internationally well-known fashion brands grew impetuously, they heavily invested on their marketing campaigns in order to compete for the attention of affluent mainland consumers as the phenomenal boom of both domestic and overseas markets still guaranteed a great economic potential. As of December 2011, the ten brands most desired by mainland Chinese consumers were Louis Vuitton, Chanel, Gucci, Christian Dior, Armani, Hermès, Rolex, Cartier, Prada and Burberry (Bain \& Company 2011).

Hong Kong's fashion scene exhibits these and many other luxury brands in its high streets and shopping malls. As Chadha and Husband (2006) have pointed out, the 
establishment of large department stores, arcades and shopping malls in Hong Kong within the last decade (more updated examples include Heritage 1881, Elements and the International Finance Centre Mall), has been of paramount importance for both the customers and luxury marketers. Indeed, the 'malling' of Hong Kong and the rest of Asia has in fact been vital for the prosperity of fashion and luxury brands.

There are now more luxury brands with flagship stores in the Greater China market and these have in some cases overtaken their originally franchised multi-label distributors. Examples include the Bluebell Group and the ImagineX Group (Chevalier and Lu 2010). They once helped international brands such as Louis Vuitton, Jimmy Choo and Coach develop local or regional awareness, but those brands have progressed to running their own directly operated stores both in Hong Kong and on the mainland.

\section{Co-creation of fashion value}

Overall, what fashion marketers sell is to a very large extent not a physical product but augmented fashion brand value nurtured by their ongoing branding and communication activities. The notion of fashion value depends on the cultural context - Chinese culture in this discussion - making it much more complex than explaining product categories. The notion of 'fashion' is fabricated from texts and images; 
selling fashion products means creating specific psychological perceptions about different types of fashion or the uniqueness of brand values (Easey 2009). However, fashion as a whole is never a stable idea. It keeps evolving in each market and society under the influence of what are usually called 'fashion trends' or 'trendsetting' (Millan, Pelsmacker and Wright 2013).

But fashion communication is not all one-way from the supplier. It is semiotic and symbolic. Meanings, fashion values, are mutually created and interpreted (Barnard 1996). On one level it seems that senders can control the meanings, but in the decoding stages the receivers' subjective interpretations of the brand come into play. 'The codes of encoding and decoding may not be perfectly symmetrical. The degrees of symmetry [...] depend on the degrees of symmetry/asymmetry (relations of equivalence) established between the positions of [...] encoder-producer and decoder-receiver' (Hall 2008 [1980]: 237). Furthermore, the encoding process is more of an intricate negotiation involving designers, marketers, journalists, stylists, photographers and others (Tse 2013, 2014). The image eventually projected incorporates consensual alterations and appropriations. Usually, the global western brands do not fully embrace the values and beliefs inherent in Chinese or other Asian cultures, since such brands, from their inception, have been imbued with their own western traits. But maintaining the allure of fashion for global brands now requires 
understanding in global cultural terms. Successful global brands must today create a tangible sense of a global community grouping their fashionable followers in different parts of the world. While the world's markets consist of heterogeneous societies, the allure of global brands makes a contribution to homogenizing and unifying cultures in terms of their consumers' liking and taste for certain brands and their being able to buy those products. So branding has now become more complex than before.

At the same time, globalized culture and aesthetics have generated discontent. Many local consumers are dissatisfied with the fact that cultural differences are increasingly being eroded by mass-produced goods (which usually originate in the West) (Howes 1996). This suggests that global brands, even fashion brands, should adapt to the cultural values of each market in their branding and marketing communication (Lea-Greenwood 2013). According to Ger (1999: 66):

Global flows of people, money, technology and information, media images, and ideologies are diverse and complex. Although these flows are dominated by transnational corporations, they are not unidirectional: in this nexus of multiple and asymmetric interdependencies, there is interplay and reciprocity. [...] Both the center and the periphery have become more visibly diverse and differentiated. This differentiating impact of globalization strengthens or reactivates national, ethnic, and communal identities [...]. In fact, the new global cultural system actively promotes 
Here the concept of glocalization resonates with, yet goes beyond, the economic term micro-marketing: 'the tailoring and advertising of goods and services on a global or near-global basis to increasingly differentiated local and particular markets [...] [that] involves the construction of increasingly differentiated consumers' (Robertson 1995: 28-29, emphasis added). As Robertson suggests, the concept of glocalization is trans-local - it works with a generalized concept of locality (Robertson 1995: 26). In the context of fashion, the glocalization process not only triggers a battle between the encoder/producer and the decoder/consumer, but also between the primary encoder/global producer and the secondary encoder/local producer (such as the local fashion marketers/distributors) in determining the level of creolization (Befu 2007: 143). The outcome depends on their respective economic strength and their sociocultural/soft power in the local market. Creolization refers to a process in which meanings are formed and socially structured between centre and periphery (Hannerz 1992: 29). Creole cultures 'are intrinsically of mixed origin, the confluence of two or more widely separated historical currents which interact in what is basically a centre/periphery relationship' (Hannerz 1992: 264). In fashion communication the creolization process breaks through the constant pressure and guidance from the 
centre towards the periphery; facilitates multicultural creative interplay; and allows the periphery to talk back and to be actively involved in the encoding/co-creating process. Increasingly, the 'peripheral' markets produce and launch their new, increasingly attractive cultural commodities for the global market (Hannerz 1992: 265). However, to what extent the notion of creolization is applicable in the actual glocalization process of fashion in the Asian context is yet to be determined.

\section{Creating brand attributes and making them fashionable}

Exemplifying the modern, the novel, the voguish, the vicissitudes of fashion must be infinite and ever-changing. Fashion branding cannot simply rely on a formulaic, stable set of core values as McDonald's does with its 'happiness and love'. Cyclically shifting global fashion trends (Easey 2009) must encourage consumers to adapt to new 'trends' (Millan, Pelsmacker and Wright 2013) while remaining true to a brand's core identity. Indeed, this interplay of internal brand values and external fashion trends is at the heart of fashion marketing communications.

The growing significance of marketing (as a new profession and science) and branding complicates the relation between markets, media and consumer culture, and between producer and consumer in the contemporary economy, epitomizing a complex mediation of demand and supply as well as the intensified marketization 
process in the neo-liberal society (Lury 2011: 137). A widely cited epithet goes: 'A product is made in a factory; a brand is bought by a consumer' (Wang 2008: 23). The brand plays a crucial role in reversing the mode of communication between producers and consumers - now the brand precedes the product, and consumers value products based on the position they occupy in the flow of media culture. Brand identity and symbolism becomes a continuously shifting series of virtual products that consumers use and exchange as social currencies in the marketplace (Lury 2004: 10-11; Lury 2011: 152, 155). Arvidsson also argues that it was only in the 1980s that brands became the central components of the social fabric, 'something of an omnipresent tool by means of which identity, social relations and shared experiences [...] could be structured' (2006: 4-5). The rise of brands and branding represents a new and contradictory logic of informational capitalism - blurring the distinction between 'production' and 'consumption' (Arvidsson 2006: 9, 16; Fournier 1998: 344). Especially for the upwardly mobile Asian consumers, the associated brand values and consumer experiences, rather than the products themselves, are much more important (Arvidsson 2006: 4-5), because such symbolic meanings of products construct the social world (social-symbolism) and construct our self-identity (self-symbolism) (Elliott and Wattanasuwan 1998: 132), and at the same time these consumers experience the social world through brands (Holt 2002: 83). 
As a specific tool of fashion marketing, marketing communication aims at establishing a fashion brand's vivid, distinctive image and psychological position in the target consumers' minds (Lea-Greenwood 2013). Fashion magazines are a fundamental communication tool for fashion publicists, and significant fashion magazines often help even an established brand's image to develop further. In the western context, fashion magazines such as Harper's Bazaar, Elle, Grazia and Vogue are major players, and they are esteemed global brands in their own right (Lea-Greenwood 2013).

But today it is essential for fashion brands to tailor communication strategies that meet the cultural norms of specific target markets (Lea-Greenwood 2013). The assumption that imported goods will unavoidably communicate the values of their culture of origin can no longer be simply postulated (Howes 1996). For instance, the non-western markets of the Asia-Pacific and the Middle East are dissimilar to western markets culturally. The Swedish brand H\&M, for example, has collaborated with celebrities including Madonna, David Beckham and Beyoncé and with fashion labels such as Karl Lagerfeld and Donatella Versace. H\&M expanded into the home market of the celebrity or designer coincident with each of the collaborations (Lea-Greenwood 2013). The pages of the www.hm.com website are tailored for each market. The collaborators participate in promotional short films about their own cities 
which are webcast on the H\&M website (Lea-Greenwood 2013).

Culture-themed event marketing is becoming a

commonly adopted fashion communication technique in mainland China. From

January to March 2011, Chanel exhibited more than 400 paintings and drawings

(along with Chanel products) in an exhibition named 'Culture Chanel' at the Museum

of Contemporary Art in Shanghai. It presented the French label's brand story and

France's cultural heritage to mainland consumers. Cartier's 'Cartier Treasures'

exhibition in the Forbidden City (the Palace Museum) in Beijing showcased more

than 350 pieces of fine jewellery and was announced as the firm's largest-scale public

presentation in its history. From May to August 2011 Louis Vuitton exhibited its

handbags and luggage in the National Museum of China in Beijing under the name

'Louis Vuitton Voyages'. It drew much public and media attention (Lannes 2011).

As Chinese consumers are progressively attracted to

more than standard, homogenous products in response to the wave of globalization,

blending a sense of Chinese tradition and 'localness' into a brand's image can create

value for the consumer, as it enriches the brand's relevance to the Asian market.

In less affluent societies, there is a revival of localism in consumption: consumers are expressing

a return to their roots, reconfiguring global goods and their meanings to better fit local culture 
and, especially, mixing the old and the new from disparate sources. (Ger 1999: 67)

In the intricate interplay of internal brand values with external fashion trends, the encoding and decoding of such glocalized, creolized fashion meanings may be neither seamless nor symmetrical. The degrees of understanding and misunderstanding for global and local consumers are controversial (Hall 2008 [1980]: 237). Exactly how, for example, do Chinese consumers prioritize and decipher the Chinese cultural aura and the Parisian chic presented in the fashion images presented to them?

Despite the accepted utility of glocalization, high fashion clothing brands still often use their chief designers as their key presenters, exemplifying the authentic essence of fashion. Marc Jacobs or Nicolas Guesquière of Louis Vuitton, Karl Lagerfeld of Chanel, Phoebe Philo of Céline and Alber Elbaz of Lanvin are well-known examples. Such chief designers wield the power of creativity throughout the marketing communication process, and regional advertising agencies, especially in places like Hong Kong, can hardly play a significant role in art direction during the encoding process. Rather, they must simply adapt the print advertisements and visuals assigned by the creative directors at the client's headquarters, slightly adjusting the informational elements such as shop addresses and contact numbers. The regional agencies are usually closely monitored by the global communication team when 
preparing for a PR event, with central approval of the production contractors, venues, spatial designs, celebrity endorsers, guests and media partners. Overall, it is unclear whether or not nominally 'glocalized' fashion communication in and through different locales amounts to truly inclusive polyculturalism and creolization in the global fashion market (Masden 1993: 508). Perhaps it is merely a 'glocalized masquerade' to further mystify and thus perpetuate western fashion history, economics, culture and aesthetics in a more sophisticated way (Ferguson 1992: 74).

\section{Methodology}

In early 2011, I came up with the idea of conducting an empirical study of fashion industry personnel's production and negotiation of fashion meanings. Through three local fashion editors with whom I was personally acquainted, one from an international title and two from another two local publications, I started exploring the opportunity to work in any of those fashion magazines as an unpaid participant observer in the local fashion industry. Eventually Fei Fei, fashion editor of Stylistic (not its real name), successfully persuaded her chief editor and was the first one to facilitate this opportunity for me during summer 2011. Stylistic is a Hong Kong fashion magazine which publishes three different editions in Hong Kong, Taiwan and mainland China, with respective circulations of 50,000, 20,000 and 300,000 copies. 
As it was difficult to gain access to the rather enclosed fashion media industry to conduct an academic study in general, I immediately seized the chance offered. This semi-intentional step, unpredictably, provided me an opportunity to participate in and observe the unique production and negotiation of globalized fashion meanings in the greater Chinese context. As a high-end fashion magazine published across Greater China, Stylistic turned out to be a magazine displaying the traits of both global monthly fashion titles (which mainly feature Euro-American luxury fashion and lifestyle news) and local weekly fashion magazines (which also feature local street fashion, celebrity gossip and news).

This study focused on observing the staff of Stylistic and other fashion industry personnel in Greater China. The editorial work was observed in detail by attending editorial meetings and daily activities such as photo shooting sessions and press events. I, as a participant observer, contributed to writing one editorial feature during the study period. The level and duration of the participation were considered sufficient to elucidate how the magazine's personnel collaborate, dispute and negotiate. The observations were recorded in written notes and, for a more accurate visual record, photos were also recorded where it was acceptable and appropriate. Furthermore, sixteen interviews were conducted during the summer of 2011 with Hong Kong-based regional fashion marketers (see Appendix 1). They were conducted 
during my participant observation in developing an editorial feature at Stylistic. The feature's topic was 'The Fashion Network: A Fashion Marketer's Outside and Inside', exploring trends in Asian fashion marketing as interpreted by a group of experienced fashion marketers. This offered an excellent opportunity for data collection and understanding fashion industry personnel's production and negotiation of fashion meanings in the Hong Kong context.

A list of potential interviewees was compiled by reviewing the fashion brands distributed in Hong Kong by the 'big three' of international fashion - the LVMH Group, Kering (ex PPR S.A.) and Compagnie Financière Richemont SA (the Richemont Group) - and by reviewing ten previous issues of Stylistic and noting the names of those who had been featured and the advertised brands. The two methods yielded a list of 139 fashion labels for consideration. The fashion editor and a womenswear fashion reporter eliminated 83 brands on various grounds, leaving 55 candidates. An invitation e-mail and twelve proposed interview questions were sent to a manager responsible for marketing at each of the 55 target brands. About half of the 55 brands initially declined to grant an interview. Finally, senior communication team representatives from sixteen fashion brands agreed and were allowed to speak for their label in the one-hour interviews. Twelve of them were interviewed face-to-face, one was interviewed by e-mail, two were interviewed over the telephone, and one 
responded both by phone and by e-mail. Interviews were conducted in English or Chinese at the respective fashion firms' offices, flagship stores and press events. All interviews were audio-taped. The interviews were conducted from July to October of 2011. The feature was published in the November 2011 issue of the magazine.

Based on my participant-as-observer role, the interviews were intended to yield a feature article for Stylistic; however, the field notes and complete interview responses (including those I did not use for the feature article) were codified thematically (DeWalt and DeWalt 2002). By re-reading the collected data - field notes and interview responses - I came up with and made use of the following three key themes elucidating the then-current fashion marketing conditions in Asia: fashion communication traits in Asia, which summarizes the typical and/or evolving characteristics of fashion communications executed by the global fashion companies, such as jewellery, accessories and watches (for example, Cartier, Piaget and Van Cleef \& Arpels); high fashion (for example, Louis Vuitton, Gucci and Christian Dior); fast fashion (for example, H\&M, Topshop and Nike); cosmetics, skincare and perfumes (for example, Guerlain and Estée Lauder); multi-label distributors (for example, the Bluebell Group or the ImagineX Group); communication attitudes of global fashion firms; and the creolization of cultural values in Hong Kong fashion distributors' communication. The following part of the article is arranged according to 
this thematic structure.

\section{Results}

Fashion communication traits in Asia

Jewellery, accessories and watches

Adrian Wong, PR and Media Manager (Asia Pacific) at the Spanish luxury accessory brand Loewe owned by the LVMH Group said that being familiar with (and sticking to) different types of fashion cycles is crucial for a fashion marketer.

First a fashion marketer has to learn about the operation of the fashion cycle, say for jewellery

it's once a year [...] For Vertu [a luxury cell phone] it's twice a year [...] For a fashion brand we have to work in line with the [four seasons] cycle [...] Although the products are different, the job nature does not change much.

However, as a Malaysian Canadian, Wong says he cherished the opportunity to come to work in Asia as he deemed Europe, Canada and the United States to be weak and saturated markets with much less opportunity and exposure for fashion marketers. Peggy Choi, Communications Director (Asia Pacific) at Piaget, working for the Richemont Group for over eighteen years, said in her specialized luxury jewellery and 
watches market that there is usually a set of relatively detailed corporate

communication guidelines to follow, but at the same time a larger marketing budget to execute the communications strategies. Their target segment is elitist, affluent, educated and not easily impressed. She states:

My 'communication' role comprises advertising and public relations, meaning that on behalf of the brand [Piaget], we need to introduce the products through different means. We're responsible for communicating with the press, the clients and the VIPs [...] Most importantly to present its best and most aesthetic side to the target audiences.

Peter Cheung, Regional Marketing and Communications Director of Van Cleef \& Arpels, who has worked at the Hong Kong Tatler, Sotheby's auction house, Christian Dior and Versace, said he wanted to 'take a break' to explore other opportunities outside of fashion - implying that he perceived luxury jewellery marketing and its product cycle and trends as significantly different from fashion's. Cheung explicitly highlighted his Asian studies major in university, believing that it gave him a good foundation for understanding the diversity of culture, language, history, taste and behaviour when planning marketing and communication strategies across Asia over the past ten years: 
I have used this constantly to observe the diversity in between not only greater China (HK,

Taiwan, China) but also Korea, Southeast Asian countries, etc. It is important to be mindful and respectful of local markets' needs, and my job is to translate them to the headquarters level.

Interestingly, the senior luxury marketer also said that every time he worked for a new brand he was willing to 'adapt' to the established brand identity while 'exploring' its new possibilities in the local market at once:

You have to understand every fashion house or luxury brand has its own 'DNA', it all depends on whether or not you can accept the new identity on an open-minded and creative level $[\ldots] \mathrm{Be}$ open-minded because every time it comes to a new situation [...], it's important for being a [fashion] marketer [...] If you yourself are not changing, in that case it's difficult to handle the marketing tasks.

\section{High fashion}

Federico Tan, Head of Marketing at Diesel Asia Pacific, agreed that in the planning of promotional strategies he cherished the local market's voices: 
In our Asia-Pacific team [...] I'll just let the local marketing team manage it $[\ldots]$ A local master has his own way of doing things [...] How they think Diesel is perceived in the market; how the local culture is; that's something we try to adapt to it. We are very particular about how we integrate to the culture of whatever country or city we are in.

Having worked for the Italian brand for over six years, Tan compared Diesel with his previous employer Shanghai Tang, a Hong Kong-founded fashion label acquired by the Richemont Group,

[Richemont] is a very strong company. They know how to develop the group and the brands. But you know obviously whether Shanghai Tang or Diesel is more 'corporate' [...] [Shanghai Tang] is a bit more formal [...] We had to work more carefully, more formally. In Diesel, I think that because of the environment, here people can at the same time $[\ldots]$ have a more open conversation.

Dr Gerrit Ruetzel, CEO and President of Hugo Boss (Asia Pacific), presented his philosophy of appropriating local cultures while marketing the German brand across Asia at Business of Design Week 2011: 
Everything starts from the product, however we have to be consistent in the way we

communicate to our customers [...] Working with [the] most important chief editors from the

magazines all around the world, here's an example in Asia [...] We worked with testimonials and

celebrities, and we adapt this concept also to the local markets [...] [Also] we work with fashion

scouts all round the world to make sure whatever we develop reflects the global positioning of

Hugo Boss and doesn't end up just being a German design, because being in 124 countries, our

product design has to consider the fashion trends happen[ing] all around the world that meet the

taste of the customers.

Florance Yip, Marketing and Communication Director (Asia Pacific) at Fendi Asia

Pacific Ltd, suggested a more humanistic approach to fashion marketing in which

interpersonal communication skills and sensitivity in collaborating with all the fashion

insiders - designers, celebrities, stylists, photographers and journalists, whom she

considers mostly 'sentimental' - is of utmost importance. However, the LVMH

Group brand has adopted a highly consistent creative direction across the globe.

Although Fendi has launched a range of thematic fashion events in certain

economically important Asian cities (e.g. the Great Wall fashion show in Beijing in

2007 and the Floating Island fashion show in Seoul in 2011) no signs of any

adaptation to Hong Kong culture could be observed in its press events. 
In [fashion] marketing, no matter if you're promoting handbags or sneakers $[\ldots]$ the core theory

is similar even if the styles are essentially different $[\ldots]$ depending on the target segment. Like in

high-end fashion, we do this press event at a sumptuous hotel $[\ldots]$ set an aesthetic theme and

showcase the 'Fendi lifestyle', resembling the ambience of an art exhibition. This well resonates

with our products and consistent global brand image.

Seemingly, all six high fashion, jewellery and accessories brand representatives emphasized their attention to the post-industrial, globalized market situation, and the need to tailor fashion products and images that suit the specific tastes of target local customers around the world. Using local key opinion leaders such as celebrities, sport stars and famed stylists as an attractive source was highlighted repeatedly. Yet, such local endorsers and also media gatekeepers must represent and communicate a consistent set of fashion styles well-monitored by the headquarters, aligned with the corporate guidelines and the brand's established 'DNA', and also synchronized with the prevailing trends within specific fashion cycles. All eventually help construct a stable, global brand image in the long run. In the Asian context, the theorized process of glocalization of fashion meanings was not always discerned in the encoding stage. 


\section{Fast fashion}

Cher Chui, Public Relations Manager at H\&M Hong Kong, freely praised her company for providing a great deal of freedom and flexibility to her team to present the H\&M brand in a mix-and-match, crossover style, especially in editorial coverage. However, based on Chui's interview responses, she at times referred to her PR team as a 'facilitator or messenger' for the headquarters. Her local PR team had to regularly and tightly align its local communications activities with the Swedish headquarters' marketing communication direction. They mainly helped facilitate close relationships with the local fashion journalists in covering the brand's annual collaboration with a star fashion designer or international celebrity, such as the crossover campaigns with Donatella Versace in November 2011, and with Alber Elbaz in November 2010. This communications strategy appears to be flexible and freewheeling, as it orbits around a rather different fashion cycle/system and blurs the distinction between haute couture and fast fashion.

\footnotetext{
When we completed lots of public relations work, generated pretty good media coverage, and then actually witnessed the long queues outside the shop on the launch day we were immensely satisfied [see Figure 1] [...] Exactly because our brand is rather different [...] More popular in nature $[\ldots]$ Other [high-end fashion] brands usually don't have this kind of instant, direct market
} 
response.

Chui's explanation of the new trend of 'high-fashion-crossover-fast-fashion' echoes a famed line from Karl Lagerfeld when he was interviewed by a French journalist from L'Express,

One time I met a girl in the lift of my company’s building. She wore a very chic jacket in Scottish tweeds. I praised her. She told me, 'This is an H\&M item! I can't afford Chanel...' I didn't especially pay attention to its buttons and lining, but it did permeate a strong sense of fashion, and its cut was very nice too. (Tungate 2005: 75)

Nonetheless, H\&M's communication is apparently closely monitored by headquarters. Whether in a global or local context, this attitude of mixing high and fast fashion is a tactic to seize the interest of high-end fashion consumers and has already been reinforced by the popularization of fashion in the mass, global consumer market. Such (con)fusion of fast fashion style with a sumptuous feeling apparently aims at affecting consumers' decoding. In fact, in H\&M's official broadcast and print advertisements the mix-and-match style has never been highlighted. Even in editorial coverage, it was still rare to see H\&M products crossing over with local fashion brands or other fast 
fashion brands. Constant guidance from the 'centre' towards the 'periphery' seems obvious. Certainly little creative input (in either advertising or editorial coverage) and almost no sign of cultural creolization were discerned in Hong Kong.

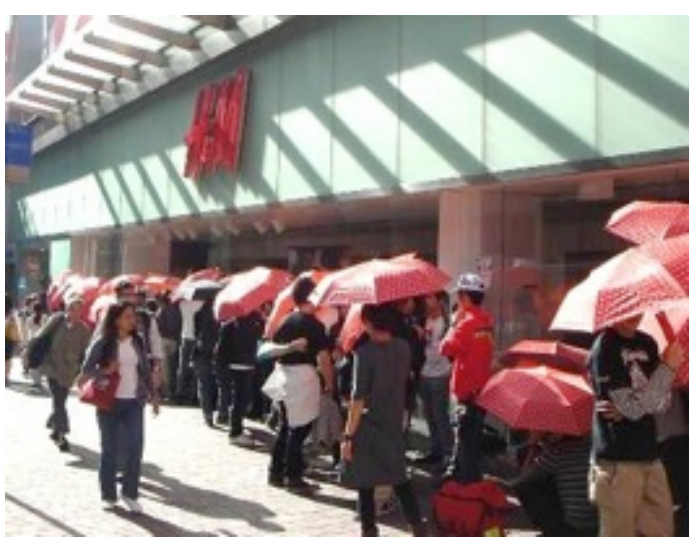

Figure 1: Long queues outside an H\&M store in Central, Hong Kong.

\section{Cosmetics, skincare and perfumes}

The comments of Maggie Cheung, Public Relations Manager of Estée Lauder (HK), suggested that the cosmetics and beauty products marketer heavily relies on endorsement by a wide range of local opinion leaders, including celebrities, stylists, professionals and socialites. The fashion and make-up styles they represent can be very diverse, too: 
for word-of-mouth marketing [...] Estée Lauder has a new product line named 'nutritious'. We

are currently collaborating with local celebrities and professionals, including Elizabeth Lee, Flora

Cheung, Coco Lee and breast cancer specialist Dr Kwong.

Cheung said that, apart from endorsing Estée Lauder in public, those endorsers were also her loyal customers because 'their well-liked public image and personal taste truly match our product traits and brand personality'.

Chester Tsung, Head of Public Relations and Makeup at Guerlain (Asia Pacific), who previously worked at the headquarters of Christian Dior and Make Up For Ever in Paris, is highly involved not just in planning a wide range of marketing communications, but also in product management, public relations, customer relationships management and visual merchandizing. He is also a practising make-up artist and stylist. He himself was the chief endorser of the brand in Asia, and regularly attended various local broadcast media programmes as well as print and online media interviews.

Instead of merely disseminating a standardized fashion message, usually perpetuated using perfect caucasian models, the two cosmetics and skincare brand publicists said they focused on facilitating target users' identification with attractive local endorsers and their particular make-up needs. Throughout the interviews, both 
marketers expressed a sense of autonomy in encoding fashionability as a specialist

professional, rather than as merely a messenger. In the cosmetics and skincare

industry a more multicultural and creative interplay of fashion meanings is facilitated.

The periphery is permitted to 'talk back' and even engaged in a co-creation process.

\section{Multi-label distributors}

Wandy Mou, Head of Marketing at Harvey Nichols (Hong Kong), explained her role

as a fashion marketer promoting over a thousand different fashion labels at once:

Because we have a variety of brands, including menswear, womenswear and accessories, there is always close cooperation between our [marketing] team and the merchandizing team, and every season we highlight a selected range of fashion brands. We need to communicate with the global headquarters of those brands to get the promotional details we need, and then think about how to disseminate the information in the local market in an effective way [...] We might simply send out press releases or we might invite their designers to Hong Kong for a tailored fashion event and exclusive face-to-face interviews.

Based on her previous work experience at Burberry and Ralph Lauren, Mou suggested that fashion marketers need to pay more attention not just to the 
international magazine titles but also to local fashion magazines, which also produce

highly aesthetic fashion editorials that resonate within the local culture:

Many international brands selectively collaborate with the international magazines only, because that would apparently relieve them from worrying about the quality of media coverage [...] Some local media are highly passionate about professional fashion journalism news too, even though they are overshadowed by the fame of their international counterparts.

She had her own view about building relationships with fashion media personnel and co-creating fashion meanings with them in the local context.

\footnotetext{
I value each of them [local fashion journalists] because you never know if this junior fashion journalist working in a local small-scaled media company will one day become the editor-in-chief of a renowned fashion media group. It would be awkward if you only befriend him then $[. .$.$] The world is round.$
}

Christine Tse, Communications Manager for the Vivienne Westwood brand at the local fashion distributor Moda Mia Ltd (Hong Kong), explained that it is essential to bring the true 'fashion experience' to local fashion journalists and offer enthusiastic 
assistance when pitching media coverage. She regularly arranges press tours to the London headquarters and to Paris fashion shows, and also facilitates product loan-outs for local fashion editorial photography. 'Vivienne Westwood's outfits are uniquely designed and they highlight a voluminous silhouette [...] They can always be worn in different ways, and we often improvise the new styles in the photography sessions... That's the fun part of the brand.' At the same time, Tse also took care of the advertising adaptation, event marketing and editorial pitching tasks. It seems that technically, there was no standard way to present Vivienne Westwood's fashion style and outfits, so the local marketer could inject a certain level of creativity and improvise while communicating the brand through locally organized press events and editorial coverage.

Global fashion firms: Communicating 'glocal' fashion meanings as we know it? Case one: The LVMH Group

It was in 1979 that the Hong Kong/Singapore fashion distributor Bluebell first established a joint venture with Louis Vuitton to expand the brand in Asia (Bluebell 2013). In 1992 China still strictly regulated foreign companies and their marketing and distribution, but the LVMH Group unveiled its first Louis Vuitton boutique in Beijing's Palace Hotel. They quickly learned to address the growing demand from 
mainland customers for luxury products (Chevalier and Lu 2010). Louis Vuitton is globally well known for the exclusivity, sophisticated craftsmanship and premium pricing of its leather accessories and trunks. Indeed, it has become one of the most counterfeited contemporary luxury brands (Chevalier and Lu 2010). LVMH's CEO and Executive Director Bernard Arnault once explained the French holding company's branding and marketing formula as follows. First, define the 'DNA' of the brand sharply by rediscovering its history and finding the correct designer to articulate it; second, tightly control its quality and distribution; and finally, generate a powerful marketing buzz (Chevalier and Lu 2010).

Among a wide range of LVMH Group brands, one of the most memorable communications campaigns was the Fendi fashion show organized on the Great Wall in December 2007. The event was large enough to raise the brand's profile in China and to be seen and talked about in Europe and the United States, as well as in Asia and other parts of the world (Chevalier and Lu 2010). As Christian Dior Couture's President and CEO Sidney Toledano has explained, their communications strategies are not limited to transplanting a consistent set of Parisian aesthetics to the Asian market; instead, they infuse Chinese cultural elements into their brand image in various ways: 
[O]ur interest in Chinese creativity is [shown by] the recent exhibition [...] at the Ullens Centre in Beijing [...] Major Chinese artists, painters, sculptors, photographers and plastic specialists gave their interpretation of the Christian Dior brand using its dresses, its aesthetic values, its iconic accessories, and the ambiance of its boutiques as sources of inspiration [...] [They] shared with $[\ldots]$ the general public what makes Dior a synonym for luxury.

In the interview with Peter Cheung, he also briefly talked about his eight-year experience as the Marketing and Communication Director at Christian Dior (Asia Pacific). In the process of mediating the global marketing direction from the Paris headquarters and brainstorming communications strategies for the Asian markets, Cheung remarked that in a global fashion giant like LVMH the process is rather top-down technically, but there was still space for negotiation:

The challenge was to persuade the head office in Paris $[\ldots]$ We are situated in the agent zone $[\ldots]$ For sure we could always make a request $[\ldots]$ Back then my managing director very much encouraged me to 'bridge the gap' - to communicate our ideas and needs to the colleagues and global [communications] directors in the head office $[\ldots]$ But first we had to earn their trust $[\ldots]$ Let them know we had a strategic reason behind the initiatives [...] At the outset, in the years 2002 and 2003, they really didn't want to have one particular zone to develop in this way, but I 
still didn't give up and kept trying to persuade them [...] At the end they let me proceed.

He also claimed that an appropriate level of appropriation of fashion meanings could enhance brand awareness and receptivity in the local market:

[A] fashion brand like Dior demands a great deal of creativity, to do something surprising which has never been done before while maintaining the brand's spirit and inspiration [...] In fact the colleagues from the head office seldom visited the Asian markets. Many times I was the one to bring and present the reports to them in Paris.

\section{Case two: The Richemont Group}

The Richemont Group owns a variety of fashion and luxury labels including Alfred

Dunhill, Cartier, Chloé, Goyard, Lancel, Montblanc, Piaget, Shanghai Tang and Van

Cleef $\&$ Arpels. It has been active in marketing its premium brands across the Asia-Pacific region for the past two decades. Alfred Dunhill's performance in the Asian market has been especially remarkable - globally the brand saw US\$12 million in losses in the first half of 2007/08, but during the same period its sales in the Asia-Pacific region contributed around US\$400 million in sales to the brand, which was around 60 per cent of Dunhill's total sales, and the figures continued to rise 
steadily (Chevalier and Lu 2010). In the area of marketing communication, the British luxury goods brand began actively to sponsor events in the 1980s, organizing both annual and boutique branding events in addition to its collaboration with luxury car manufacturer Bentley to create exclusive leather luggage (Chevalier and Lu 2010). In the interview, Peggy Choi, Communications Director (Asia Pacific) at Piaget, explained that the brand Piaget has a well-defined corporate communication direction and guidelines, including internationally-adopted advertising visuals, product images and the 'Piaget rose' and 'Piaget hearts' as the classic icons: 'To establish a [luxury] brand identity like Piaget requires a long period of time [...] Many resources are needed, and a standardized direction and set of guidelines are essential too.' However, she explained that the company interpreted its guidelines liberally, and her team might take the guidelines as opportunities to be creative rather than as restrictions. As a consequence, some creative ideas could be implemented to project the brand's image and the presumed meanings of fashion and luxury could be altered or elaborated upon further:

Two months ago we organized a charity event named 'Heart to Heart'. We have a series of heart-shaped jewellery items - one of our iconic products - but as hand accessories they are too delicate and tiny to draw the attention at a press event $[\ldots]$ At the end our creative idea was to 
invite different [celebrity] guests and give them a tailored T-shirt with the 'Piaget heart' print [...]

[We] donated a specified amount of money to the charity according to the number of guests wearing the branded T-shirts to the event.

As Choi described it, the fun part of being a luxury marketer was that she did not have to (and could never) directly adapt the global communications messages to the Asian market. Her motto was 'always keep your ears and eyes open'. By taking a lot of pictures everywhere she accumulated much visual inspiration for her marketing communications - from media promotion to the spatial design and decoration of luxury events, from electronic direct marketing to global packaging design:

\footnotetext{
Many people may disagree with my own perspective, but I still believe there is no such thing called 100 per cent creativity [...] I very much appreciate the term 'copyativity' - partly copying and partly creating $[\ldots]$ When you see others' design work you gain certain inspiration $[\ldots]$ That's my philosophy of creativity.
}

Hong Kong fashion distributors: Creolizing local cultural values in fashion communication

Case one: Harvey Nichols 
Harvey Nichols is owned by Dickson Concepts (International) Ltd. Dickson Concepts developed into a major luxury distributor from its former watch-manufacturing business. It has a strong presence in greater China, with 228 stores in mainland China, 68 in Hong Kong and 170 in Taiwan. Its total sales are around US\$400 million annually (Chevalier and Lu 2010).

Wandy Mou, the Head of Marketing at Harvey Nichols, related her previous work experience at single-brand companies and explained that their communication systems typically emphasized following headquarters' marketing direction, only slightly adjusting it to the local context. At Harvey Nichols the reverse is true: the head office is in Hong Kong, and she has greater power to initiate bold and original ideas in presenting the partnered fashion brands through media advertising, public relations, shop window displays (see Figure 2) and spatial designs at corporate fashion events:

We have pretty much space to flex our creative muscles in advertising and event planning [...] as long as they go along with the company's business goals, my boss' strategic direction and the set budget limit [...] Before each project starts, we propose the creative ideas to the management team [...] such as those responsible for producing our custom Harvey Nichols Magazine. 
Mou thus has a chance to work with freelance photographers, stylists, writers and models in producing advertising visuals and fashion photography herself. They exchange ideas and improvise the intended styles, mood and fashion images together, which is very rare for other fashion brands. This is mostly done by their creative directors themselves or occasionally by a famed photographer or a renowned creative agency.

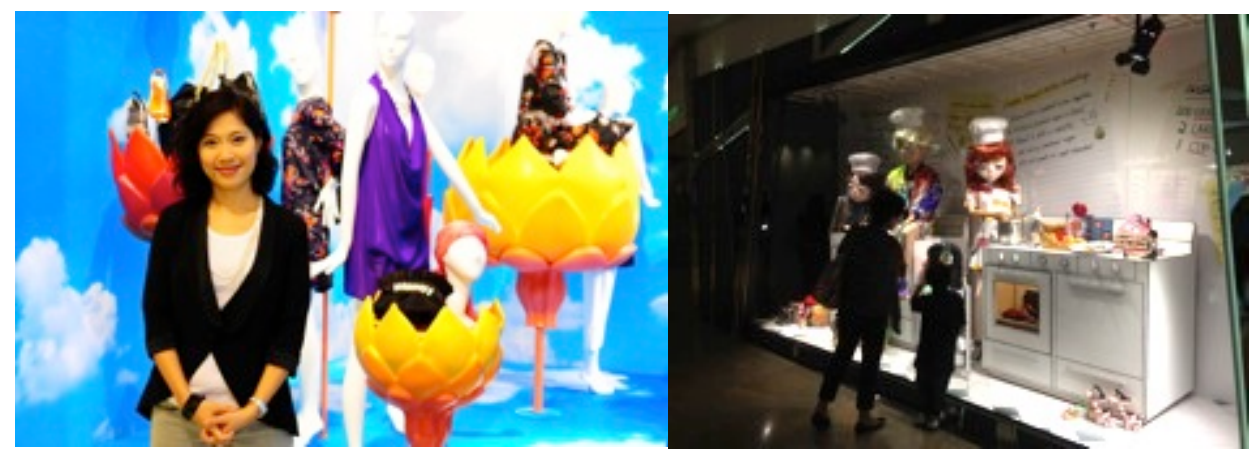

Figure 2: Harvey Nichols. The window display at Harvey Nichols in 2011 (left) \& 2015 (right).

When asked why in her case the local distributor had so much power in encoding

'Hong Kong style' fashion, Mou explained that

Some of those developing fashion labels still do not have their stand-alone retail stores in Hong Kong [...] so they seek to work with the distributors like I.T. [Apparels Ltd.], Joyce 
are receptive to their brand and products [...] As a distributor, because each [distributor] has at least over a hundred brands in hand, they actually decide which fashion brands to push, how much money to invest and how to promote them.

Hence even for renowned fashion brands, in most cases their Asian distributors still wield the power to determine what creative direction and communication strategies to adopt for the local market. For the less exclusive brands like those available in more than one distributor's retail stores, Mou said strategically distributors tend to invest less in marketing communications, as people can buy those products from the competitors' stores, for instance at Lane Crawford or I.T. Apparels. Overall, whether or not a fashion label is more intensively advertised and visibly promoted affects both its standing in the global fashion world, its perceived exclusivity and its potential profitability in the local market:

Let's say there is a quite famous and established western brand that is planning to enter the local market and willing to distribute its products exclusively at Lane Crawford. Of course there are a lot of things discussed and negotiated behind the scenes. For example, the local distributor has promised to invest an agreed amount of money for advertising and organizing promotional events to boost the fashion brand [...] Well, that's the way it is! 


\section{Case two: The ImagineX Group}

Created in 1992 by Peter Woo, the ImagineX Group is one of the strongest fashion distributors in both the Hong Kong and mainland markets. The group has been actively establishing partnerships with and assisting upcoming international fashion brands to step into the Greater China market, handling their business development all the way from distribution and retail operations to marketing communications. It operates in 43 cities and represents 22 international brands in mainland China. Successfully established ones include agnès b, BCBG Max Azria, DKNY, Dolce \& Gabbana, Hugo Boss, Marc Jacobs, Salvatore Ferragamo and Versace. Its business covers several Greater Chinese regions - apart from its Hong Kong headquarters, ImagineX has regional offices in Shanghai, Beijing and Taiwan (Chevalier and Lu 2010).

Dawn Chan, who previously majored in fashion retailing at a local university and worked for the Bluebell Group (another significant local fashion distributor), was the Marketing Manager at the ImagineX Group. In the previous five years she had been assigned to different franchised labels, including Tumi, BCBG Max Azria, Marc Jacobs and Coach, and eventually she focused on the American label Marc Jacobs. To establish the prestigious American brand Marc Jacobs in the local market, Chan says 
she constantly collaborated with teams within the fashion company such as the sales and visual merchandising departments and introduced local ideas in her communication strategies. Chan said that since Marc Jacobs's main line has a history of less than twenty years and the second line Marc by Marc Jacobs has merely ten, compared with other labels, the corporate guidelines for marketing and communication were rather loose:

New York provides us a high level of creative flexibility, yet there are many fashion companies out there which would impose very restrictive rules in branding and promotion [...] [With Marc Jacobs] the company [headquarters] seldom says no to any sensible promotional ideas [...] We want to build a short-term pop-up store (see Figure 3) in Harbour City [a major high-end shopping mall in Hong Kong], and as we perceive the 10-year anniversary of Marc by Marc Jacobs as a significant milestone for the brand, we thought of using the Chinese cross-and-circle board game 'aeroplane chess' as the theme [...] Nobody did this before, so when we proposed it to the American headquarters, they immediately liked the idea and believed it would suit the Hong Kong market.

Two years after the interview, Chan reported that as the profit-making potential in the Greater Chinese market became more evident, and LVMH expanded in the Asian 
market and took more control of overseas operations, the creative directions and marketing communications strategies proposed by the local distributor became more closely monitored, with the result that the previous glocalized creative flexibility was gradually reduced.

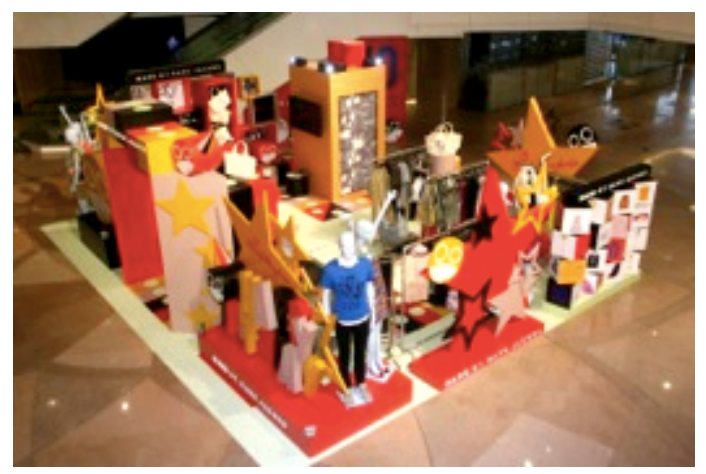

Figure 3: Marc by Marc Jacobs. Pop-up store in Harbour City, Tsim Sha Tsui, Hong Kong. 2010.

\section{Conclusions}

The rise of the fashion industry in mainland China and Hong Kong and the way in which the brands are marketed is attracting the attention of international fashion companies. The interview responses showed that fashion marketing communication does include the appropriation and negotiation of social and cultural meanings.

Deriving and encoding fashion meanings appropriate for supporting a brand's advertising requires consensus between international and local fashion marketers, 
with both sides needing to negotiate how best to interpret such meanings. Even though the global fashion industry has taken more note of the Greater China fashion and luxury markets since 1997, and though it is recognized that more appropriation and adaptation of local culture is vital, Euro-American culture continues to determine what is fashionable, and the global fashion companies, especially the successful ones, project their choices to the Asia-Pacific region through their marketing communications. They strive to control the presentation of their brands' advertising and promotion messages. In Hong Kong's case, global fashion marketers appear to have more power than the local Asian marketers. Still, headquarters and the regional marketing team may now negotiate more often, and through the 'bottom-up' approach there are examples of Asian cultural elements being accepted into fashionable offerings.

The examples of glocal fashion communication, featuring and fusing a globally coordinated brand image with constructed 'trans-local' traits, show that the Asian fashion marketers were involved in complicated negotiations with their head offices in the communication process. Asian fashion marketers do have some opportunities to define Asian styles with a creolized outlook - most of the time rather superficial, but sometimes more genuine. While the 'global' (actually western) fashion enterprises like LVMH and Richemont allegedly support infusing Asian/Chinese cultural values 
and aesthetics into their fashion meanings, the actual marketing communication that results does not always show much tendency toward creolization. This is indicative of how luxury and fashion brands divergently interact with and exploit both local and global cultures while communicating fashion meanings. The differences depend to some extent on the nature of their business (high fashion, fast fashion, cosmetics, jewellery, accessories). Some Asia-based fashion marketers, especially those working for the Asian multi-brand fashion distributors, narrated examples of successful negotiation with the headquarters to re-create globally coordinated fashion messages for local promotion. As the 'periphery', they perceived themselves as having a socio-economic advantage and as being able to reverse to some extent the power relations and tactics used by the 'centre' in creating a hybridized fashion style. Fashion meanings converge and diverge as global fashion conglomerates, local consumers and other socializing agents compete to define and redefine what is fashionable to their own groups (Kjeldgaard and Askegaard 2006). In such cases, fashion messages can be generated and disseminated in a glocalized and creolized process, giving prominence to local cultural values in emerging markets. 


\section{Appendix 1}

\section{Marketing Personnel Interviewed}

Adrian Wong

Alex Tang

Anson Shum

Amy Schmitt Seabolt

Cher Chui

Chester Tsung

Pacific) Ltd

Christine Tse

Dawn Chan

Florance Yip

Federico Tan

Gloria $\mathrm{Yu}$

Maggie Cheung

Ning Lau
PR \& Media Manager (Asia Pacific), Loewe Hong Kong Ltd

Head of Sales \& Marketing (Greater China), MCM (Mode

Creation Munich)

Head of Communication (Asia Pacific), Hugo Boss HK Ltd

PR \& Communication Director, Lane Crawford

PR Manager, H\&M Hennes \& Mauritz Ltd

Head of Public Relations and Makeup, Guerlain (Asia

Public Relations \& Communication Manager, Vivienne

Westwood at Moda Mia Ltd

Marketing Manager, Marc Jacobs at ImagineX

Marketing and Communication Director (Asia Pacific),

Fendi Asia Pacific Ltd

Head of Marketing (Asia Pacific), Diesel Pacific Ltd

Communication Manager, I.T. Apparels Ltd

Public Relations Manager, Estée Lauder Hong Kong Ltd

Vice President of Marketing, Communications and Creative, 
Joyce Boutique Holdings Ltd

Peggy Choi Communication Director (Asia Pacific), Piaget

Peter Cheung Marketing and Communications Director (Asia Pacific), Van

Cleef and Arpels

Wandy Mou Head of Marketing, Harvey Nichols (Hong Kong) Ltd

\section{References}

Arvidsson, A. (2006), Brands: Meaning and Value in Media Culture, London/New York: Routledge.

Bain \& Company (2010), 'China luxury market study 2010', http://goo.gl/w6thiH. Accessed 7 September 2012.

_ (2011), 'China luxury market study 2011', http://goo.gl/NEeN5g. Accessed 7 September 2012.

— (2013), 'Worldwide luxury goods continues double-digit annual growth', http://goo.gl/lxfqKB. Accessed 8 July 2013.

Barnard, M. (1996), Fashion as Communication, London: Routledge.

Befu, H. (2007). "“Japanization”, “Asianization of the West" and "creolization": A perspective from Japan', in P. Bowles, H. Veltmeyer, S. Cornelissen, N. Invernizzi \& K.L. Tang (eds), National Perspectives on Globalization, 
Basingstoke: Palgrave Macmillan, pp. 139-53.

Bluebell (2013), 'Milestone', http://hk.bluebellgroup.com/en/about/milestone/.

Accessed 27 July 2013.

Chadha, R. and Husband, P. (2006), The Cult of the Luxury Brand: Inside Asia's Love Affair with Luxury, London/Boston, MA: Nicholas Brealey Publishing.

Chevalier, M. and Lu, P. (2010), Luxury China: Market Opportunities and Potential, Singapore: John Wiley \& Sons.

Chevalier, M. and Mazzalovo, G. (2008), Luxury Brand Management: A World of Privilege, Singapore: John Wiley \& Sons.

DeWalt, K. M. and DeWalt, B. R. (2002), Participant Observation: A Guide for Fieldworkers, Walnut Creek: AltaMira Press.

Easey, M. (ed.) (2009), Fashion Marketing, Oxford: Wiley-Blackwell.

Elliott, R. and Wattanasuwan, K. (1998), 'Brands as symbolic resources for the construction of identity', International Journal of Advertising, 17: 2, pp. 131-44.

Ferguson, M. (1992), ‘The mythology about globalization', European Journal of Communication, 7: 69, pp. 69-93.

Fournier, S. (1998), 'Consumers and their brands: Developing relationship theory in consumer research', Journal of Consumer Research, 24: 4, pp. 343-53.

Ger, G. (1999), 'Localizing in the global village: Local firms competing in global 
markets', California Management Review, 41: 4, pp. 64-83.

Hall, S. (2008 [1980]), ‘Encoding/Decoding’, in N. Badmington and J. Thomas (eds), The Routledge Critical and Cultural Theory Reader, Oxon: Routledge, pp. 23444.

Hannerz, U. (1992), Cultural Complexity: Studies in the Social Organization of Meaning, New York: Columbia University Press.

Holt, D. B. (2002), 'Why do brands cause trouble? A dialectical theory of consumer culture and branding', Journal of Consumer Research, 29: 1, pp. 70-90.

Howes, D. (1996), 'Introduction: Commodities and cultural borders', in D. Howes (ed.), Cross-cultural Consumption: Global Markets, Local Realities, London/New York: Routledge, pp. 1-16.

Hung, K. H., Li, S. Y. and Belk, R. W. (2007), 'Glocal understandings: Female readers' perceptions of the new woman in Chinese advertising', Journal of International Business Studies, 38: 6, pp. 1034-51.

King, A. (1991), 'The global, the urban, and the world', Culture, Globalization and the World-System, London: Macmillian Education, pp. 149-54.

Kjeldgaard, D. and Askegaard, S. (2006), 'The glocalization of youth culture: The global youth segment as structures of common difference', The Journal of Consumer Research, 33: 2, pp. 231-47. 
Lannes, B. (2011), 'Chinese luxury market', Harvard Business Review, June, pp. 2229.

Lea-Greenwood, G. (2013), Fashion Marketing Communication, Chichester: John Wiley \& Sons.

Lehmann, U. (2000), Tigersprung: Fashion in Modernity, Cambridge, MA: MIT Press.

Leung, K., Bhagat, R. S., Buchan, N. R., Erez, M. and Gibson, C. B. (2005), 'Culture and international business: Recent advances and their implications for future research', Journal of International Business Studies, 36: 4, pp. 357-78.

Lury, C. (2004), Brands: The Logos of the Global Economy, London/New York: Routledge. (2011), Consumer Culture, Cambridge: Polity.

Masden, R. (1993), 'Global monoculture, multiculture, and polyculture', Social Research, 60: 3, pp. 493-511.

Millan, E., Pelsmacker, P. and Wright, L. T. (2013), 'Clothing consumption in two recent EU member states: A cross-cultural study', Journal of Business Research, 66: 8 , pp. $975-82$.

Mooney, A. and Evans, B. (eds) (2007), Globalization: The Key Concepts, London/New York: Routledge. 
Pieterse, J. N. (1995), ‘Globalization as hybridization', in M. Featherstone, S. Lash and R. Robertson (eds), Global Modernities, London: Sage, pp. 45-68.

Robertson, R. (1995), 'Glocalization: Time-space and homogeneity-heterogeneity’, in M. Featherstone, S. Lash and R. Robertson (eds), Global Modernities, London: Sage, pp. $25-44$.

Svendsen, L. (2006), Fashion: A Philosophy, London: Reaktion.

Tungate, M. (2005), Fashion Brands: Branding Style from Armani to Zara, London: Kogan Page.

Tse, H. L. T. (2013), 'This is not an LV bag: The simulacra of fashion in and beyond the media business in Hong Kong and mainland China', Ph.D. thesis, Hong Kong: University of Hong Kong. (2014), 'Fashion media communication in Hong Kong', International Journal of Fashion Design, Technology and Education, 7: 2, pp. 66-74.

Wang, J. (2008), Brand New China: Advertising, Media, and Commercial Culture, Cambridge, MA: Harvard University Press.

Zhao, J. (2013), The Chinese Fashion Industry: An Ethnographic Approach, London/New York: Bloomsbury. 


\section{Contributor details}

Tommy Tse is an Assistant Professor in the Department of Sociology, University of

Hong Kong (HKU). He specializes in gender studies, literary and cultural theory,

fashion communication and the creative industries in Asia. His work has appeared in the Asian Journal of Business Research (MAGScholar), International Journal of Fashion Design, Technology and Education (Taylor \& Francis), Clothing

Cultures (Intellect) and Luxury Brands in Emerging Markets (Macmillan). He has experience in marketing and advertising with various media companies and creative agencies, including ADO and TBWA. He has taught at the School of Communication of the Hong Kong Baptist University; the Department of Fashion and Image Design at the Hong Kong Design Institute (HKDI); and the Culture and Media Domain at HKU SPACE.

Contact: Department of Sociology, Room 9.09, The Jockey Club Tower, University of Hong Kong, Pokfulam, Hong Kong.

E-mail: tommyt@hku.hk 